\title{
Prosthesis Mapping and Forecasting as a Direction of Innovation in Prosthesis Product Development
}

\author{
Isnaini Nurisusilawati ${ }^{1}$, Muhammad Yusro ${ }^{2}$ \\ ${ }^{1}$ Industrial Engineering Study Program, Faculty of Industrial Engineering and Design \\ ${ }^{2}$ Biomedical Engineering Study Program, Faculty of Telecommunication and Electrical Engineering \\ Institut Teknologi Telkom Purwokerto, Jalan D.I. Panjaitan 128, Purwokerto, Jawa Tengah \\ email : isnaini@ittelkom-pwt.ac.id \\ doi: https://doi.org/10.31315/opsi.v14i1.4579
}

Received: $10^{\text {th }}$ March 2021; Revised: $5^{\text {th }}$ May 2021; Accepted: $7^{\text {th }}$ May 2021;

Available online: $24^{\text {th }}$ June 2021; Published regularly: June 2021

\begin{abstract}
Need analysis is the first step before developing a product. Prosthesis is one of the medical equipment needed by patients with disabilities due to illness, accidents, natural disasters, or conditions from birth. There are many studies that aim to develop prosthesis products at Dr. R. Soeharso Orthopedic Public Hospital, Surakarta but no one has specifically researched the forecasting of prosthesis needs in the future and carried out mapping to see the types of prostheses that are important to develop. The aims of this study are to do need analysis with develop a preliminary map and forecast future demand of prosthesis at Dr. R. Soeharso Orthopedic Public Hospital, Surakarta. The method used was descriptive analysis and moving average forecasting of historical data on the use of prostheses. From the results, it was found that the type of prosthesis that is most produced or needed is the prosthesis below the knee and the types of prostheses that mostly used imported components were finger prostheses. The results of the forecasting of prostheses showed a stable trend and tended to increase slightly with the MAD error rate of 2.375 and MSE of 10.378 and MAPE of $36 \%$. With this accuracy, the results of the forecasting can be used as a reference for the hospital to make supplies of prosthesis components in the next period so that the time for making prostheses can be shortened. Meanwhile, for the development of the direction of innovation, recommendations for the type of prosthesis that are a priority to be developed at Dr. R. Soeharso Orthopedic Public Hospital, Surakarta is an innovation of below knee and finger prostheses by implementing lowcost product designs.
\end{abstract}

Keywords: Prosthetics; Mapping; Forecasting; Innovation

\section{INTRODUCTION}

One of the targets of the work program of Direktorat Jenderal Bina Kefarmasian dan Alat Kesehatan (the Directorate General of Pharmaceutical and Medical Devices) is to increase the availability, affordability, quality of pharmaceuticals and medical devices. The new challenge related to the work program is about medical equipment production. The production of medical equipment is still dominated by imports, and the local medical equipment industry is only able to provide $15 \%$ of the products in the electronic catalog of the Government Procurement Policy Institute (Direktorat Jenderal, 2015).

One of the medical equipment products is a prosthesis needed by patients with disabilities due to illness, accidents, natural disasters, or conditions from birth. Prosthesis is a medical device designed to replace certain body parts to help patients regain certain functions after having been severely injured due to an accident or disease. Prostheses circulating in the market today are reported to have disadvantages, including high prices and long manufacturing waiting times (Jumena, D; Adlis, 2010) and dependence on imported products (Fauziah, R.A., Sriwarno, 2014) . In terms of disease, it is predicted that the number of people with bone disease over 50 years of age will double by 2020 (Navarro et al., 2008). Patients with these conditions will usually undergo internal repair or complete joint replacement requiring implants in the patient's body (Rahyussalim et al., 2016). 
An increase in sufferers of bone disease will certainly increase the demand for prostheses. The increasing demand for prostheses and the high price of imported prostheses has encouraged the growth of the prosthesis medical equipment industry in Indonesia. One of the hospitals that provides prosthesis manufacturing services is Dr. R. Soeharso Orthopedic Public Hospital, Surakarta.

Orthotic prosthetic installation at Dr. R. Soeharso, Surakarta is one of the health industries that has pioneered the production of orthotics and prosthetics in Indonesia. To overcome some of the shortcomings of prostheses developed in Indonesia, several studies related to the development of prosthetic product designs have been applied at the orthotic prosthetic installation at Dr. R. Soeharso, Surakarta. However, there is no need analysis yet of the need for prostheses to determine the type of prosthesis that is important to develop (Faatih, 2019).

The aims of this study are to do need analysis with develop a preliminary map and forecast future demand of prosthesis at Dr. R. Soeharso Orthopedic Public Hospital, Surakarta as a reference for innovation in the development of prosthesis products in that hospital.

\section{METHOD}

\subsection{Literature Study}

The first step taken before conducting the research was to study the literature related to prostheses and forecasting methods. Furthermore, a survey was also conducted on the condition of the prosthesis at Dr. R. Soeharso Orthopedic Public Hospital, Surakarta.

\subsection{Historical Data Collection Survey Using Prosthesis}

Historical data collection survey on the use of prostheses was conducted at Dr. R. Soeharso Orthopedic Public Hospital, Surakarta, part of the Orthotic Prosthesis Installation. The data used were primary data from the hospital which consists of historical data on the type of prosthesis, localization of the product, and the volume of use. The data collected was historical data on the use of prostheses for the last 3 years, starting from 2017 - 2019.

\subsection{Mapping of Prosthesis Type Needs Data}

Product mapping is in the form of data collection based on the needs of the type of prosthesis. In the process of prosthesis mapping, descriptive data analysis of three parameters was administered, which was the type of prosthesis used, product localization, and volume of use per month.

\subsection{Prosthesis Demand Forecasting}

The forecasting process begins with the creation of a time series plot to determine the characteristics of the historical data on the volume of prosthesis use and determine the method used according to the characteristics formed from the known historical data (Montfgomery, Douglas C; Jennings, Cheryl L; Kulahci, 2008). Figure 1 shows the historical data pattern of the use of prostheses from 20172019 at Dr. R. Soeharso Orthopedic Public Hospital, Surakarta.

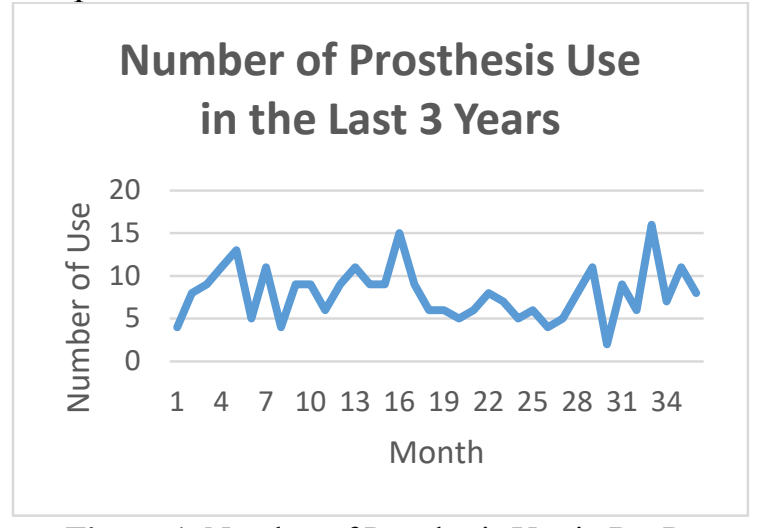

Figure 1. Number of Prosthesis Use in Dr. R. Soeharso Orthopedic Public Hospital, Surakarta in 2017-2019

From Figure 1, the pattern formed is a stationary data pattern. A time series can be implied to be stationary if the characters formed are not affected by changes in time. The DickeyFuller Test is also used to ensure the stationarity of the time series data. The procedure for testing data stationery uses the Dickey-Fuller method (Rizal \& Akbar, 2015):

a. Hypothesis formulation $\mathrm{H}_{0}: \delta=0$ (data is not stationary) $\mathrm{H}_{1}: \delta \neq 0$ (data is stationary)

b. Parameter Significance level $(\alpha)$, parameter $\delta$ and $\mathrm{SE}(\delta)$. 
c. A test statistic

$$
t=\frac{\delta}{S E(\delta)}
$$

d. Testing criteria

$$
\text { Reject } \mathrm{H}_{0} \text { if }\left|t_{\delta}\right| \geq\left|t_{(n-1 ; \alpha)}\right|
$$

Dickey-Fuller test was done using Eviews software.

The method used to process stationary data is the Moving Average Method (Montfgomery, Douglas C; Jennings, Cheryl L; Kulahci, 2008). The Moving Average method is a method used to analyze a set of information data by making predictions or looking for hidden information using the average value of a set of known data (Parekh \& Ghariya, 2015). The formula for the Simple Moving Average can be seen in Equation 1 with $M t$ is Moving Average for period t, $F_{t+1}$ is forecast for the period $\mathrm{t}+1$, and $Y_{t}$ is value of period $\mathrm{t}$.

$$
M t=F_{t+1}=\frac{Y_{t}+Y_{t-1}+Y_{t-2}+\cdots+Y_{t-n+1}}{n}
$$

\subsection{Forecasting Accuracy Testing}

There are several methods that can be used to test the accuracy of the forecasting model. In this forecasting, several methods of measuring accuracy were used, among others (Sungkawa \& Megasari, 2011):

a. MAD (Mean Absolute Deviation)

MAD is the average absolute error over a certain period regardless of whether the forecast results are greater or less than the actual data. The MAD formula can be seen in Equation 2.

$$
M A D=\sum\left|\frac{A_{t}-F_{t}}{n}\right|
$$

b. MSE (Mean Square Error)

MSE is the sum of the squares of all forecasting errors in each period divided by the number of forecasting periods. The MSE formula can be seen in Equation 3.

$$
M S E=\sum \frac{\left(A_{t}-F_{t}\right)^{2}}{n}
$$

c. MAPE (Mean Absolute Percentage Error)

MAPE is the percentage of forecast error against actual demand in a certain period. The MAPE formula can be seen in Equation 4.

$$
M A P E=\left(\frac{100}{n}\right) \sum\left|A_{t}-\frac{F_{t}}{A_{t}}\right|(4)
$$

MAPE is one of the most widely used methods of measuring forecasting accuracy (Kim \& Kim, 2016; Mckenzie, 2011).

\subsection{Estimated Trend Needs of the Number of Prostheses}

The results of the Moving Average forecast were used to see the trend of the number of prostheses in Dr. R. Soeharso Orthopedic Public Hospital, Surakarta one month ahead.

\subsection{Direction of Prosthesis Development Innovation}

Descriptive statistical analysis method was used for determining the direction of prosthesis innovation in Dr. R. Soeharso Orthopedic Public Hospital, Surakarta. Descriptive statistical analysis was conducted by collecting, classifying, summarizing, interpreting, and presenting data from a limited group, without analyzing and drawing conclusions which can be applied to a wider group (Harinaldi, 2005).

\subsection{Analysis and Recommendation}

Analysis and recommendations based on research results for Dr. R. Soeharso Orthopedic Public Hospital, Surakarta regarding the direction of innovation and the estimation of the need for the type of prosthesis.

\section{RESULTS AND DISCUSSION}

Figure 2 and Figure 3 show the data on the type of prosthesis used by Dr. R. Soeharso Orthopedic Public Hospital, Surakarta from 2017-2019. From Figure 2, it can be seen that from 2017 to 2019 , the type of prosthesis that is most produced or needed is the prosthesis below the knee with a percentage of $54 \%$. Figure 3 shows the trends in the use of each type of prosthesis each year. The prosthesis which is always increasing every year is the prosthesis below the knee and prosthesis above the knee. Meanwhile, hip and above the elbow prostheses have not been in demand for the last two years.

This is in line with research which states that the amputation of the lower limbs reaches $85-90 \%$ of all amputations and amputations below the knee are the most common type of amputation surgery and approximately $90 \%$ of patients who performed amputations below the knee were successful in using a prosthesis when compared to amputations above the knee. The 


\section{Number of Prosthesis Used in the Last 3 Years}

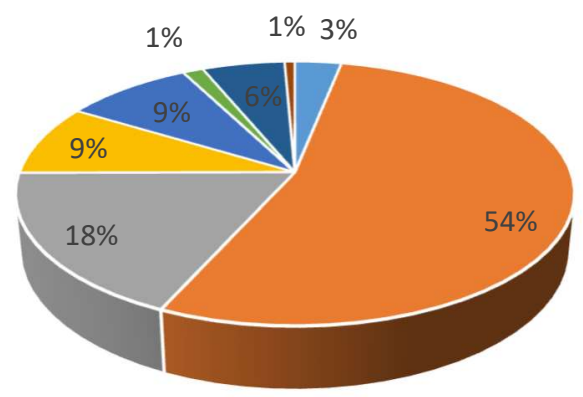

$$
\begin{array}{ll}
\| \text { Right Knee } & =\text { Below Knee }=\text { Above Knee } \\
\| \text { Syme } & \quad \text { Below Elbow }=\text { Above Elbow } \\
\square \text { Fingers } & \text { - Hip }
\end{array}
$$

Figure 2. Number of Prosthesis Used in Dr. R. Soeharso Orthopedic Public Hospital, Surakarta in the Last Three Years

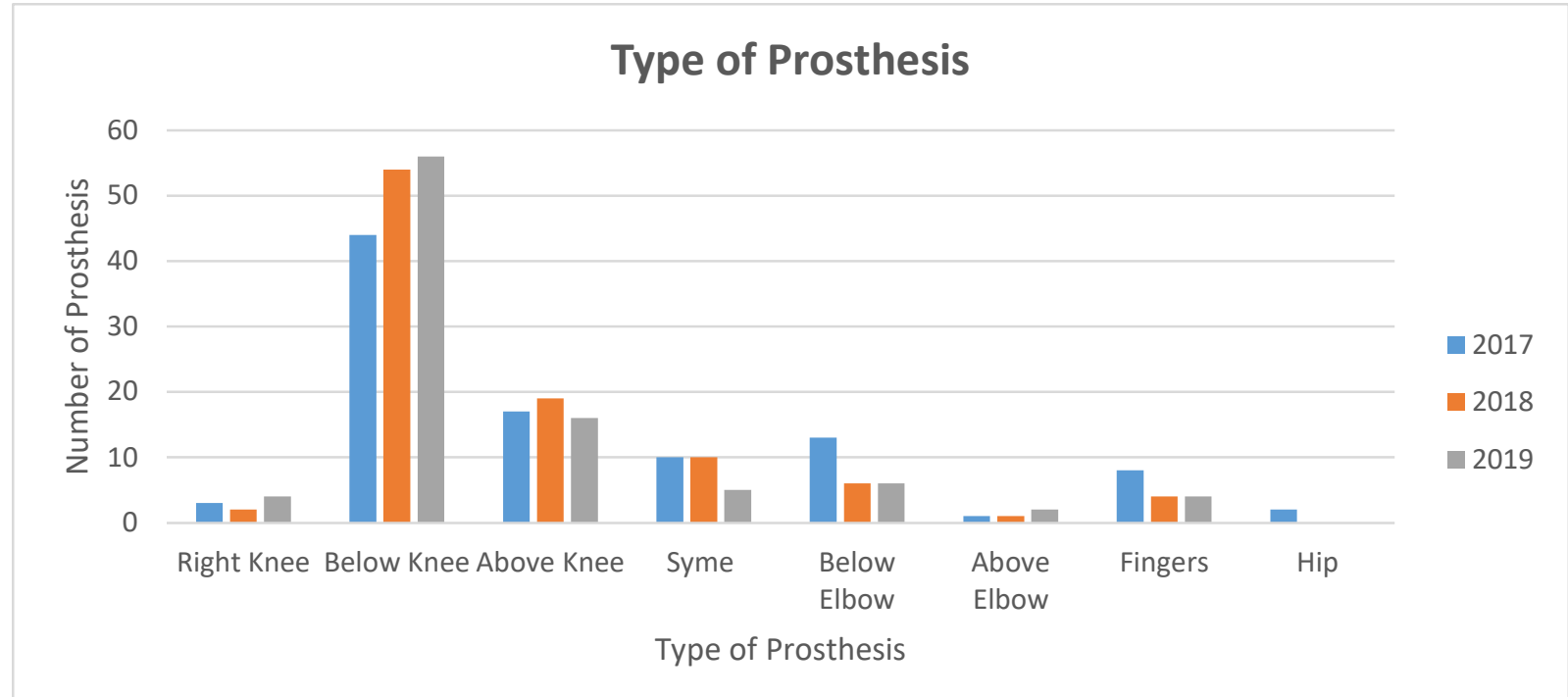

Figure 3. Distribution of the Types of Prosthesis used by Dr. R. Soeharso Orthopedic Public Hospital, Surakarta in the Last Three Years

number of amputation cases below the knee $95 \%$ due to Diabetes Mellitus (60\%), trauma (30\%), and tumors (5\%) (Prawira \& Rachmat, 2018; Suryawan et al., 2019; Vitriana, 2002).

In terms of localization of prosthetic products, Figure 4 and Figure 5 show that Dr. R. Soeharso Orthopedic Public Hospital, Surakarta has started to develop local prostheses to reduce dependence on imported prostheses which are usually expensive. The prostheses that have a big contribution to the localization of the product are the prostheses below the knee, above the knee, and Syme. The type of prosthesis that mostly uses imported components is finger prostheses. This could be an opportunity for the hospital to make innovative finger prostheses from local materials.

A prosthesis that can be developed again if the hospital wants to increase the percentage of localization of the prosthesis product is the 
finger prosthesis because this type of prosthesis contributes to the use of imported components. Hence, if the finger prosthesis is developed with local resources, the number of imported components can be reduced. Finger prosthesis is technically a complicated development of prosthesis because there are biomechanics, joints, and hand movements so that its development is not as fast as other types of prostheses. The development of the finger prosthesis system, which is widely produced in the country, mostly still uses the cable system (Sanjaya, 2010).

To overcome the problem of product localization and fulfill the increasing need for prostheses, it is recommended to develop a lowcost prosthesis design because the majority of people, especially with lower extremity disabilities, come from low economic levels (Fauziah, R.A., Sriwarno, 2014). The low-cost prosthesis design can also help people with disabilities, most of whom are still in the middle to lower economic levels, to get prosthesis services through funding from the Health Social Security Administration (BPJS).

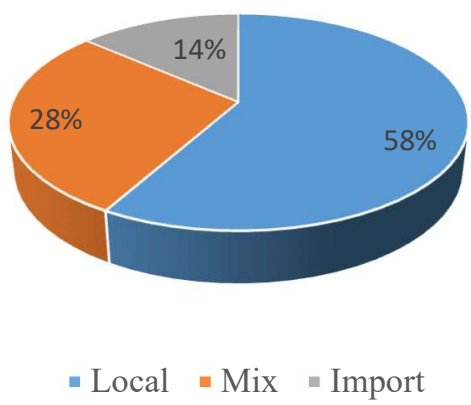

Figure 4. Prosthesis Locality Level in Dr. R. Soeharso Orthopedic Public Hospital, Surakarta

The data used in this forecast was data on the use of prostheses in Dr. R. Soeharso Orthopedic Public Hospital, Surakarta for 3 years starting from January 2017 to December 2019. Complete forecasting data can be seen in Table 1.

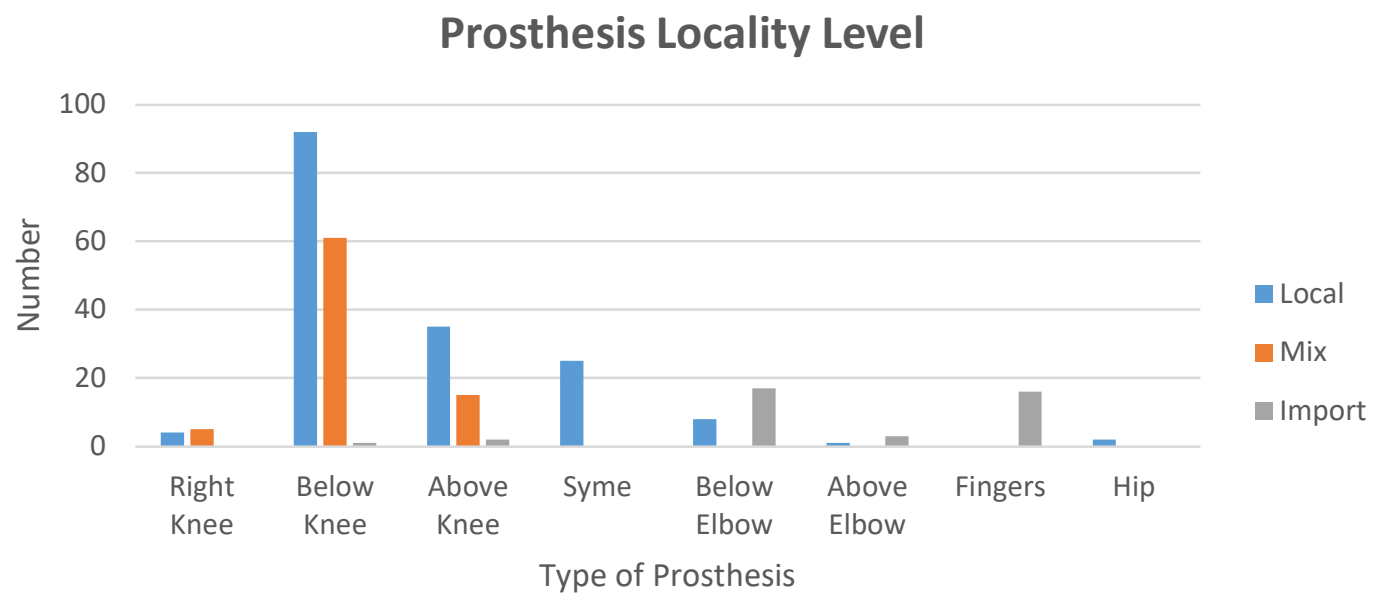

Figure 5. Data Distribution of Prosthesis Product Locality used in Dr. R. Soeharso Orthopedic Public Hospital, Surakarta from 2017-2019

Table 1. Number of Prosthesis Used in Dr. R. Soeharso Orthopedic Public Hospital, Surakarta in 2017-2019

\begin{tabular}{|c|c|c|c|c|c|c|c|c|c|c|c|c|}
\hline \multirow{2}{*}{ Year } & \multicolumn{12}{|c|}{ Month } \\
\hline & 1 & 2 & 3 & 4 & 5 & 6 & 7 & 8 & 9 & 10 & 11 & 12 \\
\hline 2017 & 4 & 8 & 9 & 11 & 13 & 5 & 11 & 4 & 9 & 9 & 6 & 9 \\
\hline 2018 & 11 & 9 & 9 & 15 & 9 & 6 & 6 & 5 & 6 & 8 & 7 & 5 \\
\hline 2019 & 6 & 4 & 5 & 8 & 11 & 2 & 9 & 6 & 16 & 7 & 11 & 8 \\
\hline
\end{tabular}


Dickey-Fuller test used to ensure the stationarity of time series data. Dickey-Fuller test calculated with Eviews software. Figure 6 shows the calculation results from Eviews software.

Null Hypothesis: JUMLAH_PROSTESIS has a unit root

Exogenous: Constant

Lag Length: 0 (Automatic - based on SIC, maxlag=12)

\begin{tabular}{lcc}
\hline \hline & \\
\hline \hline Elliott-Rothenberg-Stock DF-GLS test statistic & t-Statistic \\
\hline Test critical values: & 1\% level & -5.078858 \\
& 5\% level & -2.632688 \\
& 10\% level & -1.950687 \\
& -1.611059 \\
\hline
\end{tabular}

*MacKinnon (1996)

Figure 6. The Result of Dickey-Fuller Test with Eviews Software

From the results, we can see that $\mathrm{t}$ Statistic's value is $-5,078858$. It has an absolute value that is higher than the absolute value of critical values at all significant levels $(1 \%, 5 \%$, and $10 \%$ level). Therefore, we can reject $\mathrm{H}_{0}$ and conclude that the data is stationary.

The method used to process stationary data is the Moving Average Method. Forecasting of prosthesis products was calculated using POM QM software. POM QM software is software commonly used by companies to perform calculations as a basis for decision making. In this method, the 8-month moving average is used.
The Moving Average method shows less variability than the original data pattern (Montfgomery, Douglas C; Jennings, Cheryl L; Kulahci, 2008). From the forecasting pattern formed in Figure 7, at the end of the forecast period, the trend of the need for prosthesis in the hospital tends to increase and it is predicted continue to increase for the next month.

The results of the forecast error test are shown in Table 2. The smaller the forecast error value, the better the accuracy value. The MAPE result of $36 \%$ indicates that the forecasting accuracy is quite good (Wu et al., 2016).

Table 2. Forecast Error Test Results

\begin{tabular}{lc}
\hline $\begin{array}{c}\text { Error } \\
\text { Measure }\end{array}$ & Value \\
\hline MAD & 2,375 \\
MSE & 10,378 \\
MAPE & $36 \%$ \\
\hline
\end{tabular}

The estimated trend requirements for the number of prostheses (Figure 7) were calculated using historical data on prostheses Dr. R. Soeharso Orthopedic Public Hospital, Surakarta from January 2017 to December 2019. The results of forecasting calculations using the Moving Average method with an average of 8 months show that at the end of the forecast period, the trend of the need for prosthesis in Dr.

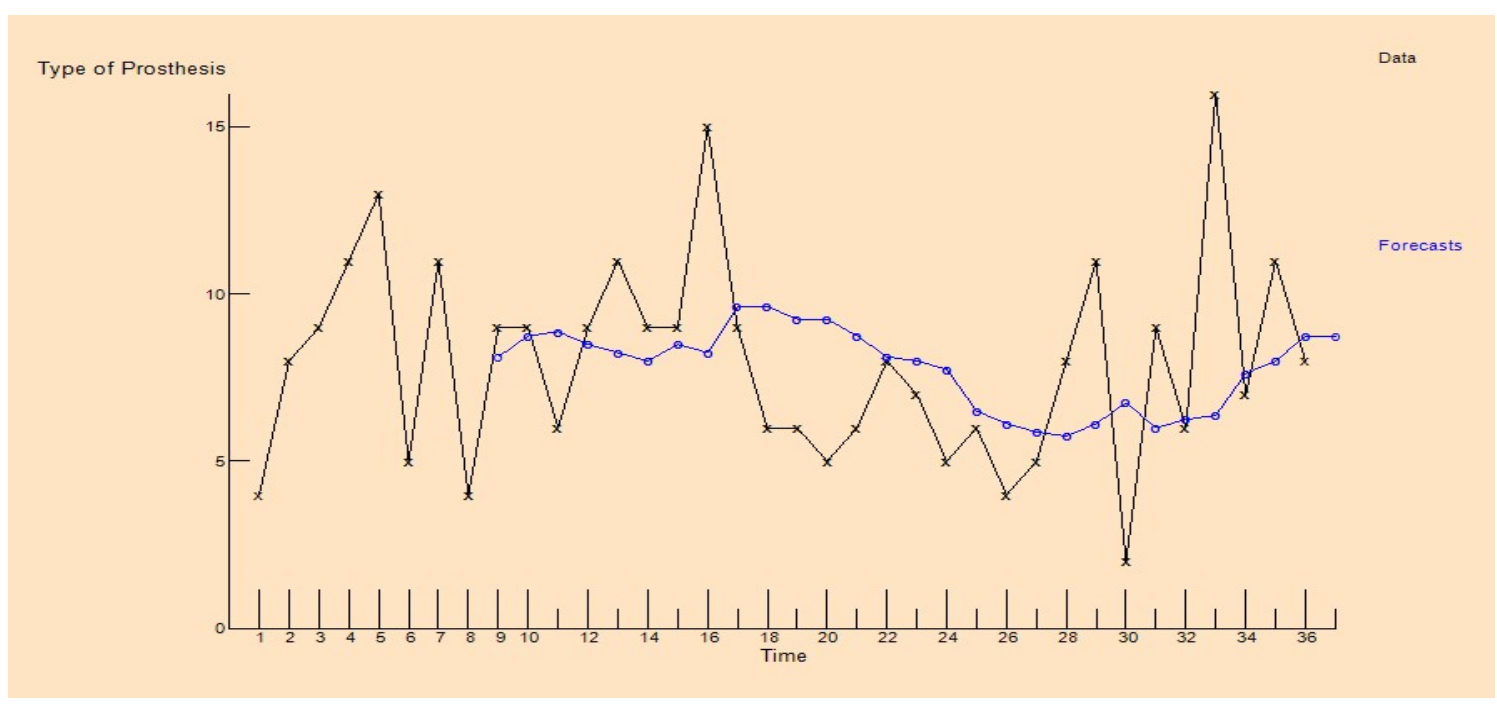

Figure 7. Forecasting Prosthesis in Dr. R. Soeharso Orthopedic Public Hospital, Surakarta 
R. Soeharso Orthopedic Public Hospital, Surakarta tends to increase.

Forecasting results have a forecasting error of $36 \%$ which indicates that the accuracy of the forecasting results can still be implied to be quite good. It is known from the forecast results that for the next month there will be a need for 9 prostheses. The results of prosthesis forecasting at RSO can be used to help orthotic and prosthetic installations plans for prosthesis's requirements and their components to avoid mismatches between initial planning and the real conditions and shorten the time for prosthesis making.

Overall, the recommendations for Dr. R. Soeharso Orthopedic Public Hospital, Surakarta regarding the innovation of prosthesis design development is the development of low costbased innovation for the type of prosthesis below the knee which is needed by many patients and the type of finger prosthesis which is mostly still dominated by imported product components.

\section{CONCLUSION}

Mapping and forecasting prosthesis in Dr. R. Soeharso Orthopedic Public Hospital, Surakarta have been successfully carried out based on historical data collected from the hospital. The demand for prosthesis tends to stable so that the hospital can make supplies of prosthesis components for the next period based on the forecasting results. It can shorten the products to be made. Innovation recommended for the hospital is an innovation for below knee and finger prostheses by applying low-cost product designs. Suggestions for further research are the research to design applications that can calculate the need of prostheses at Dr. R. Soeharso Orthopedic Public Hospital, Surakarta in the next period. Furthermore, the scope of research on mapping and forecasting the need for prostheses can be expanded so that it is able to reflect the data map of the distribution of prosthesis needs in each region of Indonesia.

\section{ACKNOWLEGEMENTS}

Thanks to the Ministry of Education and Culture for Granted the 2020 Beginner Lecturer Research Grant.

\section{REFERENCES}

Direktorat Jenderal, B. K. dan A. K. (2015). Rencana Aksi Program 2015-2019 Program Kefarmasian dan Alat Kesehatan. In Kemenkes. https://kesmas.kemkes.go.id/assets/uploa d/dir 60248a365b4ce1e/files/RENCAN A-AKKSI-PROGRAM-KESMAS-20152019-edit-11-April-2018_1023.pdf

Faatih, M. (2019). Riset Kolaboratif untuk Kemandirian Produk Alat Kesehatan: Need Assessment dan Prioritisasi Pengembangan Alat Kesehatan Dalam Negeri. In Puslitbang Sumber Daya dan Pelayanan Kesehatan Badan Penelitian dan Pengembangan Kesehatan Kementerian Kesehatan RI 2019.

Fauziah, R.A., Sriwarno, A. B. (2014). Pengembangan Desain Kaki Prostetik yang Berbasis Low-Cost untuk Industri Kecil Kaki Palsu di Indonesia. Jurnal Tingkat Sarjana Dan Desain, 1, 1-7.

Harinaldi. (2005). Prinsip-Prinsip Statistik untuk Teknik dan Sains (L. Simarmata (ed.)). Penerbit Erlangga.

Jumena, D; Adlis, A. . (2010). Desain Prosthesis Endoskeletal Bawah Lutut Untuk Penyandang Cacat. National Conference on Applied Ergonomics 2010. http://repository.unand.ac.id/88/1/Jumen o_TIUnand.doc

Kim, S., \& Kim, H. (2016). A new metric of absolute percentage error for intermittent demand forecasts. International Journal of Forecasting, 32(3), 669-679. https://doi.org/10.1016/j.ijforecast.2015. 12.003

Mckenzie, J. (2011). Mean absolute percentage error and bias in economic forecasting. Economics Letters, 113(3), 259-262. https://doi.org/10.1016/j.econlet.2011.08. 010

Montfgomery, Douglas C; Jennings, Cheryl L; Kulahci, M. (2008). Introduction to Time Series Analysis and Forecasting (Vol. 7, Issue 2). A John Wiley \& Sons, Inc., Publication.

Navarro, M., Michiardi, A., Castan, O., \& Planell, J. A. (2008). Biomaterials in orthopaedics. July, 1137-1158. https://doi.org/10.1098/rsif.2008.0151

Parekh, P., \& Ghariya, V. (2015). Analysis of Moving Average Methods. 1, 178-179. 
Prawira, H. A., \& Rachmat, N. (2018). Gambaran Penerimaan Diri Pasien Paska Amputasi Tranrtibia Setelah Menggunakan Transtibial Prosthesis. Jurnal Pendidikan Kesehatan, 7(1), 10. https://doi.org/10.31290/jpk.v7i1.242

Rahyussalim, A. J., Marsetio, A. F., Saleh, I., Kurniawati, T., \& Whulanza, Y. (2016). The Needs of Current Implant Technology in Orthopaedic Prosthesis Biomaterials Application to Reduce Prosthesis Failure Rate. 2016.

Rizal, J., \& Akbar, S. (2015). Perbandingan uji stasioner data time series antara metode: control chart, correlogram, akar unit Dickey Fuller, dan derajat integrasi. Jurnal Gradien, 11(1), 1040-1046.

Sanjaya, G. E. (2010). Eksperimen Komparasi Prosthetic Tangan Berdasarkan Pengaruh Desain Metacarpal dan Phalanx Phalangeal. Universitas Sebelas Maret Surakarta.
Sungkawa, I., \& Megasari, R. T. (2011). NILAI RAMALAN DATA DERET WAKTU DALAM SELEKSI MODEL PERAMALAN VOLUME PENJUALAN PT SATRIAMANDIRI CITRAMULIA Iwa Sungkawa; Ries Tri Megasari. ComTech, 2(2), 636-645.

Suryawan, D., Ridlwan, M., Setiadi, A., \& Kaliurang, J. (2019). Inovasi desain dan simulasi model prostesis bawah lutut berdasarkan antropometri orang indonesia. 14(1), 30-36.

Vitriana. (2002). Rehabilitasi pasien amputasi bawah lutut dengan menggunakan Immediate Post Operative Prosthetic.

Wu, L., Liu, S., \& Yang, Y. (2016). Grey Double Exponential Smoothing Model and Its Application on Pig Price Forecasting in China. Applied Soft Computing Journal, 39 ,

117-123. https://doi.org/10.1016/j.asoc.2015.09.05 4 